\title{
COPPER AND ZINC FRACTIONATION IN APPLE ORCHARD SOIL IN THE VILLAGE OF BUKEVJE (CROATIA) USING THE REVISED FOUR-STEP BCR EXTRACTION PROCEDURE
}

\author{
Gordana MEDUNIĆ ${ }^{1}$, Iva JURANOVIĆ CINDRIĆ ${ }^{2}$, Ivanka LOVRENČIĆ MIKELIĆ ${ }^{3}$, Nenad \\ TOMAŠIĆ ${ }^{1}$, Dražen BALEN ${ }^{1}$, Višnja OREŠČANIN ${ }^{4}$, Štefica KAMPIĆ ${ }^{1}$, and Ivana IVKOVIĆ ${ }^{1}$ \\ Division of Mineralogy and Petrology ${ }^{1}$, Laboratory of Analytical Chemistry ${ }^{2}$, Faculty of Science, University of Zagreb, \\ Laboratory for Radioecology, Institute Ruđer Bošković3, Advanced Energy Ltd ${ }^{4}$., Zagreb, Croatia
}

Received in November 2012

CrossChecked in November 2012

Accepted in September 2013

\begin{abstract}
The aim of this study was to establish the fractionation of copper and zinc in a small apple orchard using the revised (four-step) Bureau Communautaire de Référence (BCR) sequential extraction procedure and assess their potential mobility in soil. Soil samples were collected at the depth of $10 \mathrm{~cm}$ to $25 \mathrm{~cm}$, sixteen from the orchard and five control samples from a meadow located some $200 \mathrm{~m}$ away from the orchard. As the distribution of trace-element concentrations in the control samples was normal, they were used for comparison as background levels. We also determined soil mineralogical composition, carbonate content, soil $\mathrm{pH}$, cation exchange capacity, and soil organic matter. The extraction yields of $\mathrm{Cu}$ and $\mathrm{Zn}$ from the control soil were lower than from the orchard soil ( $25 \% v s .34 \%$ and $47 \% v s .52 \%$, respectively), which pointed to natural processes behind metal bonding in the control soil and greater influence of man-made activities in the orchard soil. Compared to control, the orchard soil had significantly higher concentrations of total $\mathrm{Cu}(P=0.0009)$, possibly due to the application of $\mathrm{Cu}$-based fungicides. This assumption was further supported by greater speciation variability of $\mathrm{Cu}$ than of zinc, which points to different origins of the two, $\mathrm{Cu}$ from pesticides and $\mathrm{Zn}$ from the parent bedrock. Copper levels significantly better $(P=0.01)$ correlated with the oxidisable fraction of the orchard soil than of control soil. Residual and organically bound copper and zinc constituted the most important fractions in the studied soils. However, the use of $\mathrm{Cu}$-based fungicides in the apple orchard did not impose environmental and health risk from $\mathrm{Cu}$ exposure.
\end{abstract}

KEY WORDS: BCR extraction, bedrock lithology, floodplain, fungicides, Sava River, trace elements

Agricultural soil is a well-studied environmental compartment, since intensive land use has been associated with inputs of soil amendments and agrochemicals (1-3) and the risk of element accumulation at phytotoxic levels. Even though copper is one of the seven micronutrients $(\mathrm{Zn}, \mathrm{Cu}, \mathrm{Mn}, \mathrm{Fe}$, $\mathrm{B}, \mathrm{Mo}, \mathrm{Cl}$ ) essential for normal plant growth (4), its excessive use in chemicals such as fungicidal sprays to control weeds and pests may adversely affect beneficial soil organisms and ultimately the entire agroecosystem. Therefore, much attention has been given to $\mathrm{Cu}$ behaviour in vineyard and orchard soils in terms of long-term or intensive use of agricultural chemicals containing this element (5-8). It is now widely recognised that micronutrient uptake by crops correlates with extractable fractions of the element in 
soils (4). Oreščanin et al. (9) found a twofold increase in $\mathrm{Cu}$ content in vineyard soil compared to the background level, most of it in exchangeable form which highly correlated with $\mathrm{Cu}$ content in grapes, most likely due to absorption from soil. More and more authors claim to be able to predict copper phytotoxicity from extractable $\mathrm{Cu}$ concentrations in soils (10-14). A number of single and multi-step extraction protocols have been developed to estimate the fraction of a micronutrient or contaminant that is bioavailable in the short term $(15,16)$. In order to harmonise methodology throughout the European Union so that the analytical results could be comparable, the Community Bureau of Référence (BCR) invented a simple, three-stage sequential extraction protocol for speciation or fractionation of trace elements in sediment and soil samples (17). The protocol was later revised to include one more stage $(18,19)$.

The aim of this study was to apply this revised BCR protocol in order to assess the potential mobility of pollutants in soil. This procedure is designed so that reagents release metals associated with specific soil phases: acid soluble, reducible, oxidisable, and residual. The first, acid soluble phase is presumed to be the most mobile, and therefor phytoavailable fraction.

Our second objective was to assemble a new set of data on the physicochemical forms of elements in an apple orchard classified between organic and conventional in terms of agricultural practices to see how it fits into the general belief - prevailing over the past few decades - that organically grown fruit is healthier and safer for consumption.

\section{MATERIALS AND METHODS}

\section{Study area}

For this study we selected a typical, small orchard (with an area of about $3750 \mathrm{~m}^{2}$ ) with dense apple tree arrangement, situated in the village of Bukevje, which is being intensively urbanised due to the near vicinity of the town of Velika Gorica and the city of Zagreb (Croatia). The orchard owner is a small apple producer, who has been applying pesticides for years, but at rates substantially lower than those used for commercial fruit production, i.e. up to five to six sprays a year. These include copper oxychloride- and dithiocarbamatebased fungicides, which contain $\mathrm{Cu}$ and $\mathrm{Zn}$, respectively. The apples are sprayed lightly using hand lances from hand-operated pumps. Otherwise, there are no major sources of pollution in the close vicinity of the study area.

\section{Geological description}

The study area is part of the Western Pannonian plain, situated in the north-west of Croatia and delimited by the hilly area of Vukomeričke Gorice to the southwest and the Sava River and its tributaries to the north, west and east. Its lithology is determined by the Sava River deposits, composed of the Quaternary sand and gravel complex in the form of three floodplain terraces. The last time the Sava flooded this area was in September 2010. The terrace consists of clastic sediments, varying from gravels to sands, and of sandy and silty clays. The gravel pebbles are mostly carbonate, then sandstone, chert, igneous rocks, metamorphic rocks, and quartz (20). According to Pavlović et al. (21), the Sava sediments are composed of low-lying carbonates and overlying silicates as a result of the intense erosive action of melting glaciers exerted on limestones and dolomites in the alpine region, followed by local inputs mainly of silicate composition. This heterogeneity of the parent material has resulted in a wide variety of soil types, but the prevailing soils are hydromorphic, including Molic and Calcaric Fluvisols, Eutric Cambisols, and Eutric and Calcic Greysols (2).

\section{Sampling and analytical methods}

Sixteen soil samples were collected from the apple orchard with a shovel as follows: a) nine samples from nine apple rows (one per row, across the orchard) at a distance of $10 \mathrm{~cm}$ to $15 \mathrm{~cm}$ from the apple tree trunk at a depth of $10 \mathrm{~cm}$ to $25 \mathrm{~cm}$ (after removing the layer of organic debris; this depth is common in geochemical mapping); b) seven samples were collected from between adjacent rows, also at the depth of $10 \mathrm{~cm}$ to $25 \mathrm{~cm}$. We did that with the assumption that the apple row samples would be more affected by agrochemicals than samples from in between rows. Five control samples were taken in the same way from an adjacent meadow, some $200 \mathrm{~m}$ away. To our knowledge, the meadow had not received any artificial inputs of $\mathrm{Cu}$, thus representing the local background metal levels.

Mineral composition was determined using a Philips PW 3040/60 X'Pert PRO powder X-ray diffractometer (PANalytical;Almelo, The Netherlands) with a CuK $\alpha$ line $(\lambda=1.54055 \AA)$ at $40 \mathrm{kV}$ and $40 \mathrm{~mA}$. 
To identify phyllosilicates, the samples were additionally treated in ethyleneglycol vapour for $24 \mathrm{~h}$ and heated at $400{ }^{\circ} \mathrm{C}$ and $550{ }^{\circ} \mathrm{C}$ for $30 \mathrm{~min}$.

Cation exchange capacity (CEC) was determined by mixing the samples with the $0.01 \mathrm{~mol} \mathrm{~L}^{-1}$ solution of copper ethylenediamine complex $\left[\mathrm{Cu}(\mathrm{en})_{2}\right]^{2+}(22)$. The subsequent change in $\mathrm{Cu}^{2+}$ concentration due to sample adsorption was determined with a ultravioletvisible spectrophotometer Hach DR/4000 U (Hach Company, Loveland, CO, USA) at $548 \mathrm{~nm}$. The $\mathrm{pH}$ of the $\left[\mathrm{Cu}(\mathrm{en})_{2}\right]^{2+}$ solution upon mixing with each sample was around 7. Soil $\mathrm{pH}$ was measured in $\mathrm{H}_{2} \mathrm{O}$.

Carbonate content was determined gravimetrically by weight loss after leaching the samples with $1 \mathrm{~mol}$ $\mathrm{L}^{-1} \mathrm{HCl}$.

Loss on ignition (LOI), as an indicator of organic matter content, was also determined by gravimetry after dry ashing at $375^{\circ} \mathrm{C}$ over $24 \mathrm{~h}$; determinations were performed in duplicate per sample.

Sample preparation and the methods used to determine $\mathrm{Cu}$ and $\mathrm{Zn}$ [energy dispersive X-ray fluorescence (EDXRF) and the revised BCR sequential extraction method] have been described earlier (23). The level of extractable copper in soil tells us how much of it is available to plants (4). As phytoavailability of metals depends on various abiotic and biotic processes, including adsorption onto and desorption from mineral surfaces, precipitation, dissolution of minerals, and interactions with soil, numerous sequential extraction schemes have been devised to assess trace metal content under different environmental conditions (e.g. $\mathrm{pH}, \mathrm{Eh}$ ), with various degrees of precision $(12,17)$. We opted for the revised BCR (1999) method because it has been widely applied to soil and sediment samples by a number of authors (15-19). The analytical verification of the method has been reported elsewhere $(23,24)$. The accuracy of the BCR method, expressed by the recovery of measured elements, ranged from $90 \%$ to $112 \%$, which is considered satisfactory. Its limits of detection are also considered acceptable for environmental analyses. The overall uncertainty of the measurement was $9 \%$ for all elements. The precision of the EDXRF method was better than $0.5 \%$ for $\mathrm{K}, \mathrm{Mn}, \mathrm{Fe}$, and $\mathrm{Ti}$, and for other elements better than $5 \%$.

\section{Statistical analysis}

Data were processed with the STATISTICA software (Version 7, StatSoft. Inc.). Normality of distribution was tested with the Shapiro-Wilk test. We used Kendall's tau correlation coefficient to evaluate the relationships between variables for every group of samples (apple row, between rows, combined orchard, and control). Differences between the groups were tested with non-parametric Kruskal Wallis and Mann-Whitney U tests.

\section{RESULTS AND DISCUSSION}

\section{Physicochemical characteristics of the soils}

Selected physico-chemical characteristics of the studied soils are listed in Table 1. Generally, these carbonate-rich soils have $\mathrm{pH}$ values within the neutral range. The average cation exchange capacity (CEC) was $114.3 \mu \mathrm{Eq} \mathrm{g}^{-1}$, which corresponds to loam and silty loam soil textures. In terms of mineral composition, the soil samples consisted of quartz (semi-quantitative range: $20 \%$ to $39 \%$ ), dolomite ( $3 \%$ to $26 \%$ ), muscovite/illite ( $29 \%$ to $52 \%$ ), plagioclase ( $7 \%$ to $13 \%$ ), chlorite (7\% to $10 \%)$, and kaolinite ( $5 \%$ to $8 \%)$. Minor chlorite-smectite occurrences were observed only in one orchard sample and in the control soil while kaolinite was found in the orchard samples but not in control. This mineral composition largely supports low CEC, whose range between $50 \mu \mathrm{Eq} \mathrm{g}{ }^{-1}$ and $250 \mu \mathrm{Eq} \mathrm{g}^{-1}$ strongly correlates with these phyllosilicate minerals (22). Considered alone, this physico-chemical profile suggests that this soil has a low potential for phytoavailable $\mathrm{Cu}$ or $\mathrm{Zn}$.

\section{Total trace element levels}

It has been widely recognised that elevated $\mathrm{Cu}$ levels in soil decrease microbial activity (6), and that $\mathrm{Cu}$ levels as low as $15 \mathrm{mg} \mathrm{kg}^{-1}$ can adversely affect earthworms (25). Wang et al. (7) have shown that fungicide-derived $\mathrm{Cu}$ in an apple orchard accounts for a large part of the total variance of soil microbial and enzyme properties and that it slows down the processes mediated by microbes. Roussos and Gasparatos (26) found lower $\mathrm{Cu}$ levels in the peel of conventionally grown than in organically grown apples, which was attributed to delayed application of $\mathrm{Cu}$-based fungicides in the organic orchard to prevent apple scab infection at the later stages of the fruit development. These studies illustrate the beneficial and detrimental effects of $\mathrm{Cu}$, but also the complexity of its behaviour following the application of pest-control chemicals. 
Table 1 Mineral and chemical properties of randomly selected control and apple orchard soil samples

\begin{tabular}{|c|c|c|c|c|c|}
\hline Sample & Mineral composition & $\begin{array}{l}\text { Carbonate } \\
\text { content } / \%\end{array}$ & pH & $\begin{array}{c}\text { LOI / } \\
\%\end{array}$ & $\begin{array}{l}\mathrm{CEC} / \\
\mu \mathrm{Eq} \mathrm{g}^{-1}\end{array}$ \\
\hline Control 1 & $\begin{array}{l}\text { Quartz, dolomite, plagioclase, muscovite/ } \\
\text { illite, chlorite, chlorite-smectite }\end{array}$ & 22.28 & 6.72 & 7.0 & 165.3 \\
\hline Control 5 & $\begin{array}{l}\text { Quartz, dolomite, plagioclase, muscovite/ } \\
\text { illite, chlorite, chlorite-smectite }\end{array}$ & 20.16 & 6.80 & 9.5 & 161.1 \\
\hline $\begin{array}{l}\text { Between apple } \\
\text { rows } 2\end{array}$ & $\begin{array}{l}\text { Quartz, dolomite, plagioclase, muscovite/ } \\
\text { illite, chlorite, kaolinite, chlorite-smectite }\end{array}$ & 20.47 & 7.38 & 11.7 & 120.8 \\
\hline $\begin{array}{l}\text { Between apple } \\
\text { rows } 10\end{array}$ & $\begin{array}{l}\text { Quartz, dolomite, plagioclase, muscovite/ } \\
\text { illite, chlorite, kaolinite }\end{array}$ & 22.09 & 7.16 & 6.8 & 67.4 \\
\hline $\begin{array}{l}\text { Between apple } \\
\text { rows } 15\end{array}$ & $\begin{array}{l}\text { Quartz, dolomite, plagioclase, muscovite/ } \\
\text { illite, chlorite, kaolinite }\end{array}$ & 24.02 & 7.23 & 7.3 & 75.4 \\
\hline Apple row 3 & $\begin{array}{l}\text { Quartz, dolomite, plagioclase, muscovite/ } \\
\text { illite, chlorite, kaolinite }\end{array}$ & 22.97 & 7.60 & 9.3 & 132.3 \\
\hline Apple row 7 & $\begin{array}{l}\text { Quartz, dolomite, plagioclase, muscovite/ } \\
\text { illite, chlorite, kaolinite }\end{array}$ & 20.78 & 7.45 & 11.6 & 116.6 \\
\hline Apple row 13 & $\begin{array}{l}\text { Quartz, dolomite, plagioclase, muscovite/ } \\
\text { illite, chlorite, kaolinite, chlorite-smectite }\end{array}$ & 23.15 & 7.23 & 11.3 & 75.5 \\
\hline
\end{tabular}

LOI - Loss on ignition; CEC - Cation exchange capacity

This raises the question about finding an optimal dose in terms of environmental protection.

To understand $\mathrm{Cu}$ and $\mathrm{Zn}$ findings (presented as range, mean and SD values in Table 2) in our apple orchard we first need to discuss the characteristics of control soil. The Shapiro-Wilk test showed moderate to perfect normality for all variables in control samples $(P=0.61$ for $\mathrm{Cu}$ and $P=0.55$ for $\mathrm{Zn})$. Normality presumes natural element composition that may serve as background data for trace elements in the study area.

In addition, we calculated Kendall's tau correlation matrix $(P<0.05)$ for $\mathrm{Al}, \mathrm{Fe}, \mathrm{Co}, \mathrm{Ni}, \mathrm{Rb}, \mathrm{Sr}, \mathrm{LOI}, \mathrm{Cu}$, $\mathrm{Zn}, \mathrm{As}$, and $\mathrm{Pb}$ (Table 2) to get a broader view of geochemical relations. The first seven variables represent conservative components, whose values are commonly unaffected by contaminant input, whereas the last four are heavy metals whose levels reflect human activity (28). The correlations are mainly positive but not statistically significant, and could have resulted from geogenic processes in soils formed by the weathering of the local bedrock lithology. In other words, these correlations in control soil could be valid for the entire study area.

With the exception of $\mathrm{Cu}$ and $\mathrm{Zn}$, total mean levels of all other variables in the orchard were nearly identical to control. In contrast, $\mathrm{Cu}$ and $\mathrm{Zn}$ in orchard samples (combined) were significantly higher than control $(P=0.0009$ and $P=0.0132$, respectively, Mann-
Whitney $U$ test), but did not exceed respective Croatian reference limits in agricultural soils of $(60$ to 90$) \mathrm{mg} \mathrm{kg}^{-1}$ and (60 to 150$) \mathrm{mg} \mathrm{kg}^{-1}$ (29). Furthermore, the differences between control and orchard sites using $\mathrm{Cu}$ and $\mathrm{Zn}$ values normalised for the LOI content were not statistically significant, which suggests that both metals have strong affinity for organic matter, as reported elsewhere (4).

We also found a deviation from normal distribution for $\mathrm{Cu}(P=0.10)$ and $\mathrm{Zn}(P=0.14)$, which is consistent with copper contamination of the orchard soil.

Similarly, Kendall's tau correlations between $\mathrm{Cu}$ / $\mathrm{Zn}$ and other variables (Table 3 ) were positive in control samples, suggesting a common geochemical origin (30). In orchard samples, several correlations were even negative, which points to different sources and/or different chemical behaviour of these elements in soil, as suggested by Abollino et al. (31) or to common geogenic processes (30).

\section{Copper and zinc fractionation}

Table 3 shows the four extraction steps that correspond to exchangeable, reducible, oxidisable, and residual fractions of $\mathrm{Cu}$ and $\mathrm{Zn}$. The ratio of total $\mathrm{Cu}$, determined with EDXRF, to extractable $\mathrm{Cu}$ (sum of steps 1 to 3) (EDXRF:EF ratio), in control samples was distinctly higher than in the apple rows and between-row samples. These ratios have a roughly 
Table 2 The Kendall's tau correlation matrix calculated for the studied soil groups

\begin{tabular}{|c|c|c|c|c|c|c|c|c|}
\hline & \multicolumn{4}{|c|}{$\mathrm{Cu}$} & \multicolumn{4}{|c|}{ Zn } \\
\hline & C & O & A & $\mathbf{M}$ & C & O & A & M \\
\hline $\mathrm{Al}$ & 0.50 & -0.03 & 0.00 & 0.21 & 0.12 & 0.11 & 0.30 & 0.10 \\
\hline $\mathrm{Fe}$ & 0.22 & -0.11 & -0.06 & 0.05 & 0.11 & 0.28 & 0.22 & 0.43 \\
\hline $\mathrm{Co}$ & 0.47 & -0.06 & 0.37 & -0.41 & 0.22 & 0.13 & 0.43 & -0.10 \\
\hline $\mathrm{Ni}$ & 0.32 & 0.00 & 0.33 & -0.52 & 0.20 & -0.10 & 0.06 & -0.33 \\
\hline $\mathrm{Cu}$ & 1.00 & 1.00 & 1.00 & 1.00 & 0.74 & 0.35 & 0.39 & 0.24 \\
\hline $\mathrm{Zn}$ & 0.74 & 0.35 & 0.39 & 0.24 & 1.00 & 1.00 & 1.00 & 1.00 \\
\hline As & 0.11 & 0.03 & 0.11 & -0.05 & 0.00 & 0.23 & 0.34 & 0.14 \\
\hline $\mathrm{Rb}$ & 0.73 & 0.11 & 0.28 & 0.05 & 0.60 & 0.41 & 0.56 & 0.43 \\
\hline $\mathrm{Sr}$ & 0.31 & 0.14 & 0.20 & -0.05 & 0.60 & 0.02 & 0.03 & -0.24 \\
\hline $\mathrm{Pb}$ & 0.53 & -0.04 & 0.08 & -0.05 & 0.80 & 0.18 & -0.20 & 0.71 \\
\hline LOI & 0.32 & 0.28 & 0.39 & 0.33 & 0.20 & 0.34 & 0.00 & 0.71 \\
\hline
\end{tabular}

Bolded figures denote significant correlations at $\mathrm{P}<0.05$; LOI - loss on ignition; $C$ - control samples, $\mathrm{n}=5$; $O$ - orchard soil samples combined $(M+A), \mathrm{n}=16 ; A$ - apple row samples, $\mathrm{n}=9 ; M$ - samples from between the apple rows, $\mathrm{n}=7)$. Al, Fe, and LOI (loss on ignition) are expressed in \%, other values in $\mathrm{mg} \mathrm{kg}^{-1}$.

Table 3 Basic statistical parameters of the total (EXDRF) and the BCR-extracted $\mathrm{Cu}$ and $\mathrm{Zn}$ values in orchard and control soil

\begin{tabular}{|c|c|c|c|c|c|c|}
\hline \multirow{4}{*}{$\begin{array}{l}\text { Decriptive } \\
\text { parameters }\end{array}$} & \multicolumn{6}{|c|}{ Mass fraction / $\mathrm{mg} \mathrm{kg}^{-1}$} \\
\hline & \multicolumn{2}{|c|}{ Control, $n=5$} & \multicolumn{4}{|c|}{ Orchard, $n=16$} \\
\hline & \multirow[b]{2}{*}{ Mean (SD) } & \multirow[b]{2}{*}{ Range } & \multicolumn{2}{|c|}{ Apple row, $n=9$} & \multicolumn{2}{|c|}{ Middle row, $n=7$} \\
\hline & & & Mean (SD) & Range & Mean (SD) & Range \\
\hline \multicolumn{7}{|c|}{ Copper } \\
\hline Step 1 & $0.00(0.00)$ & 0.00 to 0.00 & $0.00(0.00)$ & 0.00 to 0.00 & $0.00(0.00)$ & 0.00 to 0.00 \\
\hline Step 2 & $0.00(0.00)$ & 0.00 to 0.00 & $0.12(0.24)$ & 0.00 to 0.69 & $0.52(1.37)$ & 0.00 to 3.63 \\
\hline Step 3 & $0.06(0.13)$ & 0.00 to 0.31 & $3.59(1.69)$ & 0.00 to 5.72 & $4.35(6.08)$ & 0.00 to 17.53 \\
\hline Step 4 & $8.92(0.69)$ & 8.23 to 10.01 & $12.63(4.99)$ & 9.08 to 25.30 & $10.06(1.60)$ & 7.69 to 12.62 \\
\hline EDXRF & $34.96(1.97)$ & 32.80 to 37.90 & $46.70(4.31)$ & 39.00 to 53.20 & $45.80(1.66)$ & 43.30 to 48.10 \\
\hline EDXRF:EF & 582 & & 12 & & 9 & \\
\hline \multicolumn{7}{|c|}{ Zinc } \\
\hline Step 1 & $1.24(0.94)$ & 0.48 to 2.80 & $0.86(0.52)$ & 0.25 to 1.67 & $0.42(0.30)$ & 0.00 to 0.84 \\
\hline Step 2 & $10.33(2.30)$ & 8.23 to 14.11 & $10.42(1.59)$ & 7.65 to 13.26 & $12.60(1.30)$ & 11.03 to 14.15 \\
\hline Step 3 & $16.51(3.54)$ & 12.83 to 20.46 & $20.80(4.07)$ & 15.34 to 26.95 & $22.54(2.78)$ & 19.05 to 25.05 \\
\hline Step 4 & $35.67(5.07)$ & 31.77 to 44.51 & $40.09(5.08)$ & 34.61 to 48.94 & $37.91(5.27)$ & 33.75 to 46.48 \\
\hline EDXRF & $133.64(1.30)$ & $\begin{array}{c}132.30 \text { to } \\
135.70\end{array}$ & $\begin{array}{l}139.73 \\
(4.32)\end{array}$ & $\begin{array}{c}130.40 \text { to } \\
146.30\end{array}$ & $139.68(5.10)$ & 136.40 to 143.20 \\
\hline EDXRF:EF & 5 & & 4 & & 4 & \\
\hline
\end{tabular}

Step 1: exchangeable fraction; Step 2: reducible fraction; Step 3: oxidisable fraction; Step 4: residual fraction; Steps 1+2+3: extractable fraction $(E F)$

similar trend as reported by Pietrzak and McPhail (10).

Figure 1 shows $\mathrm{Cu}$ and $\mathrm{Zn}$ fractionation in all soils, where the relative fractions are in the following descending order: residual $>$ oxidisable $>$ reducible $>$ exchangeable. In contrast to orchard soil, control soil $\mathrm{Cu}$ was almost exclusively ( $>99 \%$ ) bound to the residual fraction (non-silicate bound metal, Step 4) and mineral lattice (labelled as EDXRF on Figure 1), and therefore not available to the plant under environmental conditions. This agrees with reports that metals of anthropogenic origin generally exhibit greater mobility in soil compared to metals of natural origin, which are strongly bound to soil components $(4,8)$.

The ratios of total to extractable $\mathrm{Zn}$ were rather comparable in all soils, indicating mainly geogenic origin (32). 

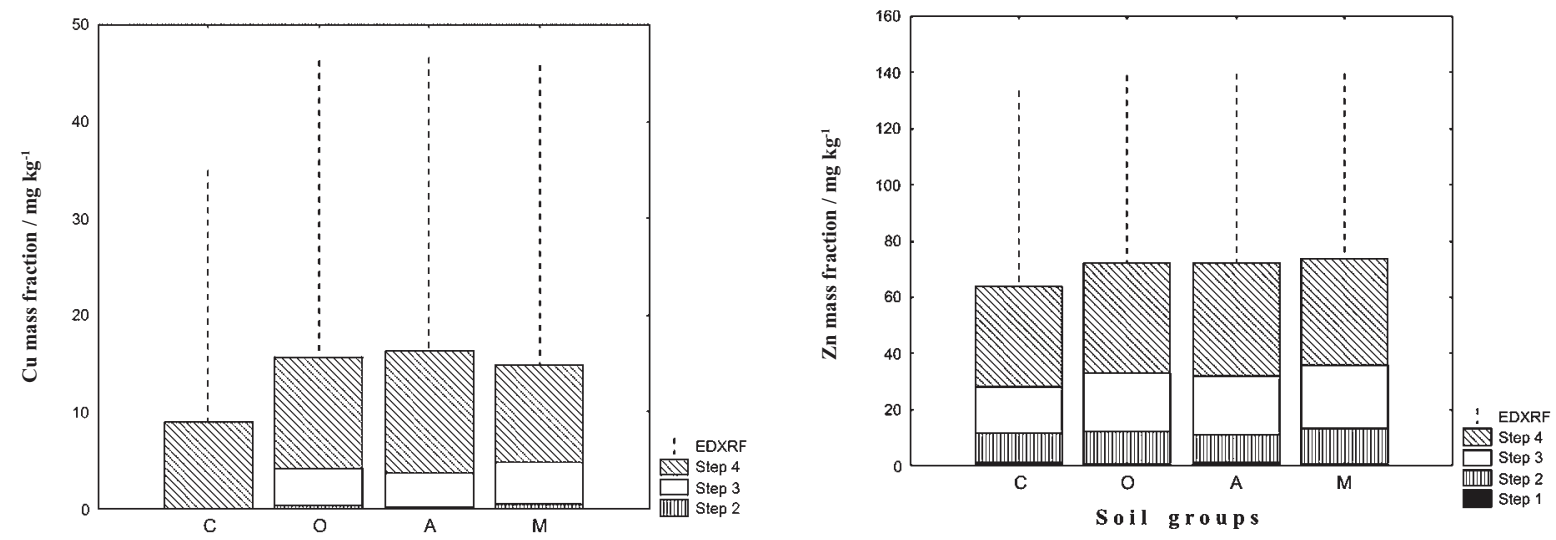

Figure 1 Chemical fractionation of $\mathrm{Cu}$ and $\mathrm{Zn}$ in the studied soils Data represent mean values. Soil groups: $C$ - control samples, $\mathrm{n}=5 ; O$ - orchard soil samples combined $(M+A), \mathrm{n}=16$; A - apple row samples, $\mathrm{n}=9 ; M$ - samples from between the apple rows, $\mathrm{n}=7$; Step 1: exchangeable fraction; Step 2: reducible fraction; Step 3: oxidisable fraction; Step 4: residual fraction.

Generally, our results are comparable with similar studies $(11,13,14,32)$. Quite expectedly, the extractable amounts were rather low due to low total metal content, neutral to alkaline properties of the soils $(4,17)$, and low CEC (Table 1), but important because they are phytoavailable.

The Mann-Whitney U and Kruskal-Wallis tests showed statistically higher $\mathrm{Cu}$ levels in the oxidisable fraction of the combined orchard and apple row soil compared to control $(P=0.01$ and $P=0.02$, respectively), which is consistent with other studies (11-14), confirming that $\mathrm{Cu}$ is one of the least mobile metals in soils due to its strong sorption on and complexation with organic matter (4). With the exception of $\mathrm{Zn}$ in control samples, the correlations between oxidisable fractions of both metals and the respective recoverable fractions (sums of steps 1-3) were highly significant $(P=0.77$ to 0.99$)$. This points to sorption on organic matter as the most important retention mechanism for $\mathrm{Cu}$ in the studied apple orchard soil.

\section{Acknowledgement}

We are truly grateful to Mister Ivan Haluga from Velika Gorica (Bukevje), who kindly allowed us to take soil samples from his orchard as well as his delicious apples, for this research.

\section{REFERENCES}

1. Merry RH, Tiller KG, Alston AM. Accumulation of copper, lead and arsenic in some australian orchard soils. Aust J Soil Res 1983;21:549-61. doi: 10.1071/SR9830549
2. Romić M, Romić D. Heavy metals distribution in agricultural topsoils in urban area. Environ Geol 2003;43:795-05. doi: 10.1007/s00254-002-0694-9

3. Xiaorong W, Mingde H, Mingan S. Copper fertilizer effects on copper distribution and vertical transport in soils. Geoderma 2007;138:213-20. doi: 10.1016/j. geoderma.2006.11.012

4. Adriano DC. Trace Elements in Terrestrial Environments. Biogeochemistry, Bioavailability, and Risks of Metals. New York: Springer Verlag; 2001.

5. Merrington G, Rogers SL, Van Zwieten L. The potential impact of long-term copper fungicide usage on soil microbial biomass and microbial activity in an avocado orchard. Aust J Soil Res 2002;40:749-59. doi: 10.1071/SR01084

6. Vogeler I, Vachey A, Deurer M, Bolan N. Impact of plants on the microbial activity in soils with high and low levels of copper. Eur J Soil Biol 2008;44:92-100. doi: 10.1016/j. ejsobi.2007.12.001

7. Wang Q-Y, Zhou D-M, Cang L. Microbial and enzyme properties of apple orchard soil as affected by long-term application of copper fungicide. Soil Biol Biochem 2009;41:1504-9. doi: 10.1016/j.soilbio.2009.04.010

8. Komárek M, Čadková E, Chrastný V, Bordas F, Bollinger J-C. Contamination of vineyard soils with fungicides: A review of environmental and toxicological aspects. Environ Int 2010;36:138-51. doi: 10.1016/j.envint.2009.10.005

9. Oreščanin V, Katunar A, Kutle A, Valković V. Heavy metals in soil, grape, and wine. J Trace Microprobe Tech 2003;21:171-80.

10. Pietrzak U, McPhail DC. Copper accumulation, distribution and fractionation in vineyard soils of Victoria, Australia. Geoderma 2004;122:151-66. doi: 10.1016/j. geoderma.2004.01.005

11. Moćko A, Wacławek W. Three-step extraction procedure for determination of heavy metals availability to vegetables. Anal Bioanal Chem 2004;380:813-7. PMID: 15517201

12. Menzies NW, Donn MJ, Kopittke PM. Evaluation of extractants for estimation of the phytoavailable trace metals in soils. Environ Pollut 2007;145:121-30. doi: 10.1016/j. envpol.2006.03.021 
13. Nogueirol RC, Alleoni LRF, Nachtigall GR, Wellington de Melo G. Sequential extraction and availability of copper in $\mathrm{Cu}$ fungicide-amended vineyard soils from Southern Brazil J Hazard Mater 2010;181:931-7. doi: 10.1016/j. jhazmat.2010.05.102

14. Fan J, He Z, Ma LQ, Stoffella PJ. Accumulation and availability of copper in citrus grove soils as affected by fungicide application. J Soil Sediment 2011;11:639-48. doi: 10.1007/s11368-011-0349-0

15. Quevauviller $\mathrm{Ph}$. SM\&T activities in support of standardisation of operationally-defined extraction procedures for soil and sediment analysis. In: Quevauviller $\mathrm{Ph}$, editor. Methodologies in soil and sediment fractionation studies. Cambridge: The Royal Society of Chemistry; 2002. p. 1-9.

16. Rao CRM, Sahuquillo A, López-Sánchez JF. A review of the different methods applied in environmental geochemistry for single and sequential extraction of trace elements in soils and related metarials. Water Air Soil Pollut 2008;189:291-33. doi: $10.1007 / \mathrm{s} 11270-007-9564-0$

17. Bacon JR, Davidson $\mathrm{cm}$. Is there a future for sequential chemical extraction? Analyst 2008;133:25-46. doi: 10.1039/ b711896a

18. Rauret G, López-Sánchez JF, Sahuquillo A, Rubio R, Davidson C, Ure A, Quevauviller Ph. Improvement of the $\mathrm{BCR}$ three step sequential extraction procedure prior to certification of new sediment and soil reference materials. J Environ Monitor 1999;1:57-61. doi: 10.1039/A807854H

19. López-Sánchez JF, Sahuquillo A, Rauret G, Lachica M, Barahona E, Gomez A, Ure AM, Muntau H, Quevauviller $\mathrm{Ph}$. Extraction procedures for soil analysis. In: Quevauviller $\mathrm{Ph}$, editor. Methodologies in soil and sediment fractionation studies. Cambridge: The Royal Society of Chemistry; 2002. p. 28-65.

20. Šikić K, Basch O, Šimunić A. Osnovna geološka karta SFRJ, 1:100000. Tumač za list Zagreb [Basic geological map of Yugoslavia, 1:100000. Geology of Zagreb Sheet, in Croatian] Beograd: Savezni geološki zavod Beograd i Institut za geološka istraživanja Zagreb; 1979.

21. Pavlović G, Prohić E, Tibljaš D. Statistical assessment of geochemical pattern in overbank sediments of the river Sava, Croatia. Environ Geol 2004;46:132-43. doi: 10.1007/s00254004-1019-y
22. Van Olphen H, Fripiat JJ. Data Handbook for Clay Materials and Other Non-Metallic Minerals. Oxford: Pergamon Press; 1979.

23. Zeiner M, Juranović Cindrić I, Lovrenčić Mikelić I, Medunić G, Kampić Š, Tomašić N, Stingeder G. The determination of the extractability of selected elements from agricultural soil. Environ Monit Assess 2013;185:223-9. doi:10.1007/ s10661-012-2546-8.

24. Oreščanin V, Lovrenčić Mikelić I, Mikelić L, Lulić S. Applicability of MiniPal 4 compact EDXRF spectrometer for soil and sediment analysis. X-Ray Spectrom 2008;37:50811. doi: $10.1002 / x r s .1079$

25. Helling B, Reinecke SA, Reinecke AJ. Effects of the fungicide copper oxychloride on the growth and reproduction of Eisenia fetida (Oligochaeta). Ecotoxicol Environ Saf 2000;46:108-16. PMID: 10806001

26. Roussos PA, Gasparatos D. Apple tree growth and overall fruit quality under organic and conventional orchard management. Scientia Horticulturae 2009;123:247-52. doi: 10.1016/j.scienta.2009.09.011

27. Matschullat J, Ottenstein R, Reimann C. Geochemical background - can we calculate it? Environ Geol 2000;39:9901000. doi: $10.1007 / \mathrm{s} 002549900084$

28. Salomons W, Förstner U. Metals in the Hydrocycle. BerlinHeidelberg: Springer-Verlag; 1984.

29. Pravilnik o zaštiti poljoprivrednog zemljišta od onečišćenja [Regulations on the protection of cultivated land from contamination, in Croatian]. Narodne novine 032/2010.

30. Halamić J, Galović L, Šparica M. Heavy metal (As, Cd, Cu, $\mathrm{Hg}, \mathrm{Pb}$ and $\mathrm{Zn}$ ) distribution in topsoil developed on alluvial sediments of the Drava and Sava Rivers in NW Croatia. Geol Croat 2003;56:215-32.

31. Abollino O, Giacomino A, Malandrino M, Mentasti E, Aceto M, Barberis R. Assessment of metal availability in a contaminated soil by sequential extraction. Water Air Soil Pollut 2006;137:315-38. doi: 10.1007/s11270-005-9006-9

32. Arias M, Lopez E, Soto B. Copper distribution and fractionation in aggregate fractions from vineyard soils: comparison with zinc. Agrochimica 2005;49:60-9. 


\title{
Sažetak
}

\section{KEMIJSKI OBLICI BAKRA I CINKA U TLU NASADA JABUKA U SELU BUKEVJE (HRVATSKA) ISPITIVANI REVIDIRANOM BCR EKSTRAKCIJSKOM SHEMOM U ČETIRI KORAKA}

\begin{abstract}
Analizirani su uzorci tla iz obiteljskog voćnjaka u selu Bukevju kako bi se utvrdilo ponašanje metala u tragovima u okolišu u kontekstu poljoprivrednih postupaka proteklih nekoliko desetljeća. Unos kemijskih sredstava za zaštitu bilja navodno je nizak. Nakon provedene tzv. BCR sekvencijske ekstrakcijske analize, kemijski oblici bakra i cinka razmotreni su iz geokemijskoga/geološkoga gledišta. Uzeto je šesnaest uzoraka tla iz voćnjaka te pet uzoraka kontrolnog tla s obližnje livade. Analize su obuhvaćale određivanje mineralnog sastava tla, kationsko izmjenjivačkog kompleksa (KIK), pH tla i gubitka žarenjem. Koncentracije mjerenih varijabli u kontrolnim uzorcima, određene XRF metodom, upućuju na njihove prirodne razine na temelju normalnosti raspodjela. Tlo iz voćnjaka neznatno je onečišćeno bakrom, moguće od primjene fungicida na bazi bakra, što je utvrđeno Mann-Whitneyevim U testom, koji je pokazao statistički značajno više koncentracije ukupnog $\mathrm{Cu}(P=0.0009)$ u tlu voćnjaka u usporedbi s uzorcima kontrolnog tla. Učinkovitost BCR ekstrakcije bakra i cinka izračunata za kontrolno tlo ( $25 \%$ odnosno $47 \%)$ bila je niža nego ona izračunata za tlo iz voćnjaka (34 \% odnosno $52 \%$ ). Bakar, potječući djelomice od fungicida, pokazao je veću specijacijsku varijabilnost u istraživanim tlima u usporedbi s cinkom, za koji se pretpostavlja da potječe uglavnom od trošenja stijenske podloge. Mann-Whitneyev U test pokazao je statistički značajno $(P=0,01)$ više vrijednosti $\mathrm{Cu}$ povezane s frakcijom tla iz voćnjaka podložnoj oksidaciji u odnosu na istu frakciju kontrolnih uzoraka. Bakar i cink u istraživanim tlima čvrsto su vezani za rezidualnu i organsku frakciju, a ukupne im vrijednosti ne premašuju maksimalno dopuštenu količinu onečišćujućih tvari u poljoprivrednom zemljištu, pa ne bi trebali predstavljati toksikološku opasnost za ljudsko zdravlje.
\end{abstract}

KLJUČNE RIJEČI: BCR ekstrakcijska analiza, fungicidi, litologija podine, poplavna ravnica, rijeka Sava

\section{CORRESPONDING AUTHOR:}

Gordana Medunić

Division of Mineralogy and Petrology

Department of Geology

Faculty of Science, University of Zagreb

Horvatovac 95, HR-10000 Zagreb, Croatia

E-mail:gpavlovi@inet.hr 